\title{
Problems of water utilization in different climatic conditions (on the example of Belarus)
}

\author{
Piotr Lopuch, Yulia Hledko*, and Wang Hao \\ Belarusian State University, Leningradskaya 16, 220030, Minsk, Belarus
}

\begin{abstract}
The article substantiates the necessity for current adjustment of the hydrological districting of the territory of the Republic of Belarus following the transformation of the conditions for the formation of surface flow and the obsolescence of hydrological data on flow monitoring, the emergence of a new climatic factor in the formation of the hydrological regime of rivers.
\end{abstract}

\section{Introduction}

The problem of water resources optimal use is the main task of modern water utilization. Business entities improve and develop methods for studying the conditions of flow formation, assessing quantity and quality, management, rational use and protection of water resources. Natural and anthropogenic factors in the territory of a particular state determine its state water cadastre. Features of the water cadastre shaping conditions are determined mainly by climatic factors.

One of the scientific approaches to the optimal utilization of water resources is hydrological districting. The experience of hydrological districting of the USSR territory can conditionally be expressed in three principles: basin, landscape (natural, or physical and geographical conditions for the formation of flow, listed according to the classical scheme of the complex geographical characteristics of the basin) and the hydrological.

The basin principle of hydrological districting of the USSR territory reflected the scale of the state and was based on the allocation of hydrological districts along the basins of large rivers. Within Belarus, these were mainly the basins of the Dnieper (Black Sea basin), the Western Dvina and the Neman (the Baltic Sea basin) [1]. In the 1960s, a more detailed hydrological districting of the territory of Belarus was offered [2]. The basin approach is the organizational basis for hydrological calculations and forecasts, including the qualitative and quantitative assessment of water resources.

\section{Research methods}

In the study we used both traditional geographical research methods - descriptive, cartographic, comparative-geographical, mathematical-statistical, and modern methods geographical monitoring and GIS technologies.

\footnotetext{
* Corresponding author: gledko74@mail.ru
} 
Mathematical and cartographic methods were used to analyze the spatial structure of changes in the annual, maximum and minimum river flows of Belarus during the period of climate warming. For the conditions of Belarus, a boundary year was defined as 1989 since in this year climate change towards warming was identified, being synchronous with global climatic processes [3].

The degree of influence from physical and geographical factors on various hydrological characteristics of surface flows over different periods of averaging (long-term, annual, seasonal, daily) can vary significantly. Each factor changes in space and time. Therefore, the quantitative characteristics of flows as integral indicators reflect the spatial and temporal patterns regarding their distribution within the studied area. Taking into account these differences, we used the method of digitalized thematic maps application, including hydrological ones (we used the software ArcGIS and Adobe Illustrator) [4].

One should bear in mind the temporal nature of hydrological calculations. Actually, the hydrological principle in hydrological districting, carried out in the middle 1960s, was implemented on the basis of monitoring the surface flows at the beginning of the calculation period. Unfortunately, the hydrological districting has not changed or even been corrected since that time. At the same time, significant changes in the conditions of flows formation took place on the river catchments, the main of which was the transformation of the catchments nature caused by land reclamation measures, increase in the anthropogenic regulation of flows in large rivers and local flows. Quantitative indicators of flows for the second half of the $20^{\text {th }}$ century are naturally not taken into account in modern hydrological districting.

Methodological approaches for hydrological districting of the territory of Belarus using the described method were also tested on the example of a separate province of China Guizhou.

\section{Research results}

The current hydrological districting of the territory of Belarus was based on a comprehensive geographical approach, which takes into account a number of geographical factors and conditions for the formation of surface flows. The core of each hydrological district is the river catchments of the largest rivers of Belarus: the Western Dvina, the Viliya, the Neman, the Pripyat, the Dnieper (or their main part), Fig. 1.

First of all, the integrated approach to the hydrological districting is a landscape assessment of the catchment area, conditions of flow formation. In this respect, the role of geology, topography, soils, quantitative indicators of the physical and geographical conditions of catchments, the degree of their development, and the natural and artificial regulation of surface flows were taken into account. However, the boundaries of the districts do not always coincide with the boundaries of the river basins. The only Neman hydrological district coincides with the basin. However, it is shown without the allocation of subdistricts in the layout. The discrepancy between the hydrological districts regarding the norm of precipitation over the territory of Belarus is shown in Fig. 1.

As a result of thematic maps overlapping characterizing the current conditions for the formation of surface flows and the pattern of current hydrological districting in Belarus, its obsolescence was proved. An analysis of the spatial distribution of modern environmental conditions in Belarus indicates a violation of the basin principle in the layout of hydrological districts and sub districts.

The transformations of the hydrographic network, anthropogenic regulation of surface flows, reclamation transformations of river basins, unstable climatic conditions caused by global warming, and new quantitative characteristics of flows do not agree with the previously identified taxonomic units. 


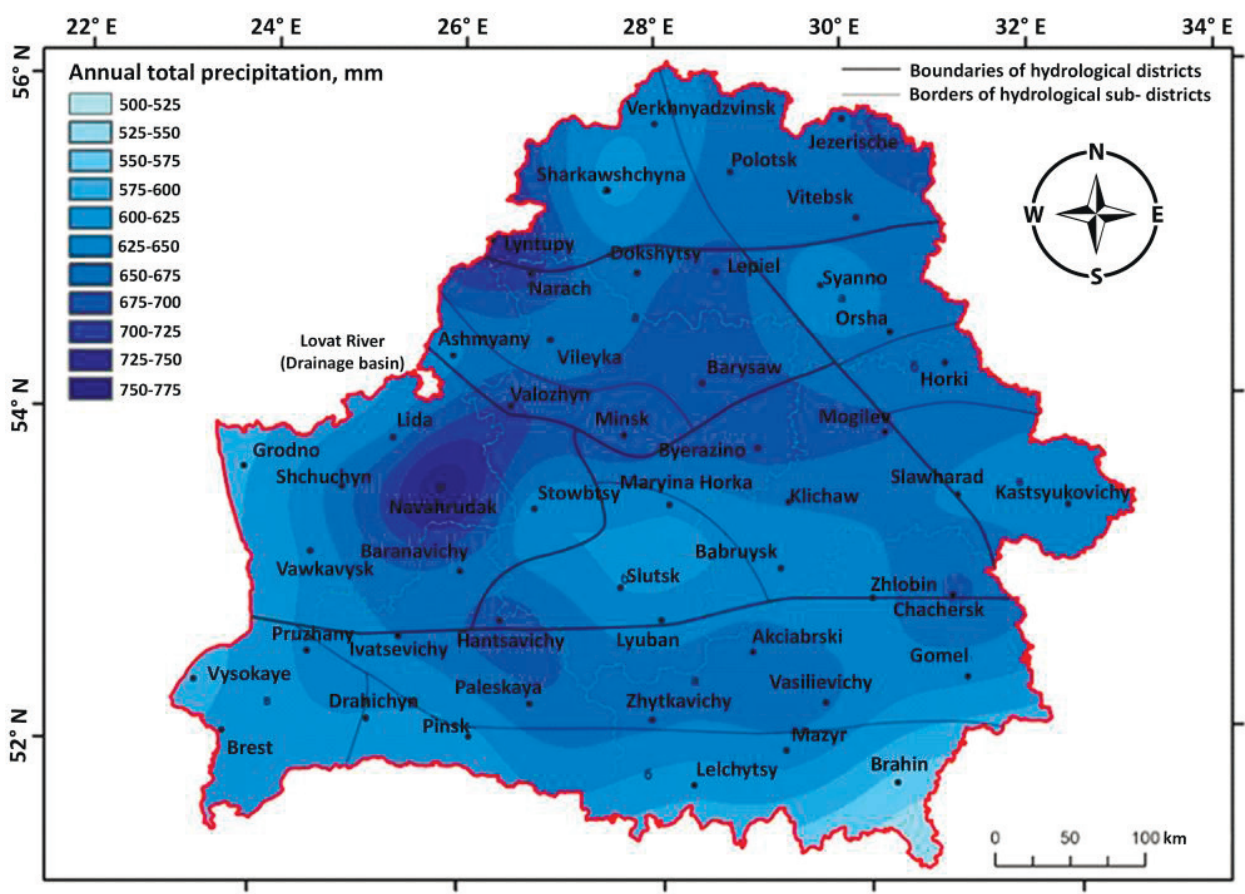

Fig. 1. Overlapping of the existing hydrological districting of Belarus on the map of the annual precipitation distribution.

The analysis of maps prepared in different years also showed comparative stability in the distribution of flows in Belarus. Temporary changes are most often caused by climatic conditions that emerged in 1989. Large-scale land reclamation has a great influence on the flow change.

When analyzing the maps, inconsistencies were noted in the current conditions of flow formation [5-6], confirming the necessity to develop a new map of hydrological districting of Belarus, which, along with the updated data, ensured more accurate modern methods of layer-by-layer mapping for the flow formation conditions to be applied and a significantly larger number of hydrological characteristics [7] to be taken into account. Taken as a complex, the noted features of the methodological approaches allow hydrological districting to be more justified (Fig. 2).

\section{Conclusions}

Based on the substantial actual material on river flow accumulated by the hydrometeorological service of Belarus, updated maps of indicators affecting the flow have been compiled with the help of software, which made it possible to carry out a new (adjusted) districting of the territory of Belarus.

The boundaries of all districts in Belarus were close to the boundaries of their basins. The isoline of the mean annual flow module amounted to $4.01 / \mathrm{s}$ per $\mathrm{km}^{2}$ and the boundary of the Western Bug basin allowed identifying a new district - the Western Bug - in the west of the Pripyat Polesye. Subdistricts were allocated in the Western Dvina district (western and eastern subdistricts, based on the isoline of $7.01 / \mathrm{s} \mathrm{per} \mathrm{km}^{2}$ of the average annual flow module), the Dnieper district (western and eastern, the allocation is based on the border of the Dnieper and the Sozh river basins), the Pripyat district (northern and southern, based on the differences in the natural factors of the formation of the right and the 
left stream tributaries of the Pripyat) and the Western Bug district (Podlasko-Predpolesky and Polessky, based on differences in topography and average annual rainfall).

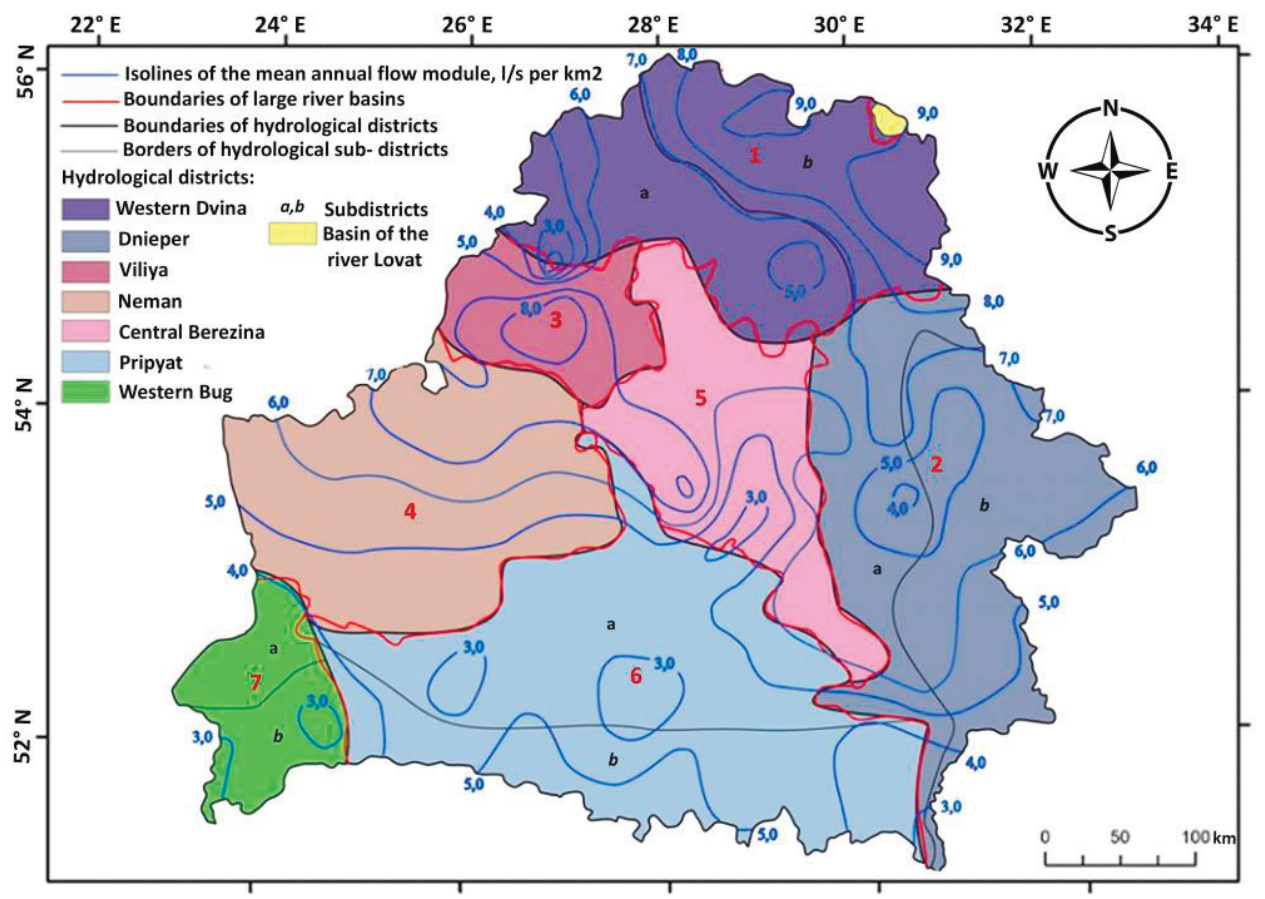

Fig. 2. Project of a new (adjusted) hydrological districting of the territory of Belarus.

The performed hydrological districting of the territory of Belarus has both practical and theoretical significance. The materials attached can be used in practice of hydraulic engineering, when conducting hydrological calculations and forecasting dangerous hydrological phenomena in the basins of major rivers.

\section{References}

1. V.V. Drozd, Water resources of Belarus: methodology, structure, assessment, forecast (Minsk, 2010)

2. P.S. Lopuch, Hydrography of Belarus: study guide for BSU students of the geographical faculty (Minsk, 2004)

3. V.F. Loginov, A.A. Volchek, Water balance of river catchments in Belarus (Minsk, 2006)

4. K.A. Karpechenko, P.S. Lopuch, Topical scientific, technical and environmental issues of habitat conservation: scientific articles International Scientific and Practical Conference. Part 4. (2014)

5. A.A. Makarevich, BSU Bulletin. Ser. 2. (2001)

6. V.F. Loginov, A.A. Volchek, V.V. Luksha, Natural resources. 1 (2003)

7. P.S. Lopuch, K.A. Karpechenko Problems of hydrometeorological support of economic activity in a changing climate: materials of the International Scientific Conference (Minsk, 2015) 